\title{
Mushroom poisoning in Hong Kong: a ten-year review
}

\author{
CK Chan *, HC Lam, SW Chiu, ML Tse, FL Lau
}

\section{A B S T R A C T}

Introduction: Mushroom poisoning is a cause of major mortality and morbidity all over the world. Although Hong Kong people consume a lot of mushrooms, there are only a few clinical studies and reviews of local mushroom poisoning. This study aimed to review the clinical characteristics, source, and outcome of mushroom poisoning incidences in Hong Kong.

Methods: This descriptive case series review was conducted by the Hong Kong Poison Information Centre and involved all cases of mushroom poisoning reported to the Centre from 1 July 2005 to 30 June 2015.

Results: Overall, 67 cases of mushroom poisoning were reported. Of these, 60 (90\%) cases presented with gastrointestinal symptoms of vomiting, diarrhoea, and abdominal pain. Gastrointestinal symptoms were early onset ( $<6$ hours post-ingestion) and not severe in 53 patients and all recovered after symptomatic treatment and a short duration of hospital care. Gastrointestinal symptoms, however, were of late onset ( $\geq 6$ hours post-ingestion) in seven patients; these were life-threatening cases of amatoxin poisoning. In all cases, the poisonous mushroom had been picked from the wild. Three cases were imported from other countries, and four collected and consumed the amatoxin-containing mushrooms in Hong Kong. Of the seven cases of amatoxin poisoning, six were critically ill, of whom one died and two required liver transplantation. There was one confirmed case of hallucinogenic mushroom poisoning caused by Tylopilus nigerrimus after consumption of a commercial mushroom product. A number of poisoning incidences involved the consumption of wild-harvested dried porcini purchased in the market.

Conclusion: Most cases of mushroom poisoning in Hong Kong presented with gastrointestinal symptoms and followed a benign course. Life-threatening cases of amatoxin poisoning are occasionally seen. Doctors should consider this diagnosis in patients who present with gastrointestinal symptoms that begin 6 hours or more after mushroom consumption.
Hong Kong Med J 2016;22:124-30
DOI: 10.12809/hkmj154706
CK Chan *, Dip Clin Tox (HKPIC \& HKCEM), FHKAM (Emergency Medicine)
SW Chiu, MPhil (Biology), PhD
${ }^{1}$ ML Tse, FHKCEM, FHKAM (Emergency Medicine)
${ }^{1}$ Hong Kong Poison Information Centre, United Christian Hospital, Kwun Tong, Hong Kong
School of Life Sciences, The Chinese University of Hong Kong, Shatin, Hong Kong
${ }^{1}$ HC Lam, Dip Clin Tox (HKPIC \& HKCEM), FHKAM (Emergency Medicine)
${ }^{1}$ FL Lau, FRCSEd, FHKAM (Emergency Medicine)
* Corresponding author: chanck3@ha.org.hk

New knowledge added by this study

Local epidemiology data of mushroom poisoning presented between 1 July 2005 and 30 June 2015 that include the first case series of amatoxin poisoning in Hong Kong.

- Life-threatening amatoxin poisoning was caused by consumption of Amanita farinosa. This is the first report of this Amanita species in Hong Kong.

- A confirmed case of hallucinogenic mushroom poisoning was caused by imported Tylopilus nigerrimus.

Implications for clinical practice or policy

- Public awareness of the high-risk behaviour of consuming self-picked wild mushrooms should be raised.

- A number of poisoning incidents involved the consumption of wild-harvested dried porcini purchased in the market.

- Doctors should suspect amatoxin poisoning in patients who present with gastrointestinal symptoms that begin 6 hours or more after wild mushroom consumption. Hong Kong Poison Information Centre can be consulted early to facilitate urgent mushroom identification and antidote treatment.

\section{Introduction}

Mushroom poisoning is a global phenomenon and can be a source of major mortality and morbidity. Although Hong Kong people consume a large volume of mushrooms, there are few clinical studies and reviews related to local mushroom poisoning. ${ }^{1,2}$ The diagnosis of mushroom poisoning should be based on clinical features, laboratory investigations, and mushroom identification. Due to the lack of leftover mushroom samples in most cases, emergency 
physicians and clinical toxicologists usually have to diagnose mushroom poisoning based on clinical syndromes alone without mushroom identification by mycologists. Diaz ${ }^{3}$ has reviewed and established the classification of mushroom poisoning based on the time of presentation and target organ systemic toxicity. With respect to the time of presentation, mushroom poisoning is categorised as early onset ( $<6$ hours), late onset (6-24 hours), or delayed onset ( $>1$ day). Early-onset toxicities include several neurotoxic, gastrointestinal, and allergic syndromes. Late-onset toxicities include hepatotoxic, accelerated nephrotoxic, and erythromelalgia syndromes. Delayed-onset toxicities include delayed nephrotoxic, delayed neurotoxic and rhabdomyolytic syndromes. Syndromic approaches guide earlier diagnosis and facilitate empirical treatment. ${ }^{3}$

In Hong Kong, scattered cases of mushroom poisoning are reported every year. In a report published by the Centre for Health Protection (CHP), there were 13 reported cases of wild mushroom poisoning between January 2002 and May 2005. ${ }^{1}$ Symptoms occurred 0.5 to 5 hours post-ingestion and included vomiting (100\%), abdominal pain (100\%), diarrhoea (69\%), nausea (56\%), dizziness (50\%), sweating (37\%), numbness (31\%), palpitation (19\%), malaise (13\%), fever (13\%), and headache (6\%). ${ }^{2}$ Of these patients, seven required hospitalisation and all of them completely recovered. Individual cases of mushroom poisoning have been announced in CHP press releases from time to time. In another report, seven patients presented with mainly gastrointestinal symptoms after wild mushroom consumption between May 2007 and August 2010. ${ }^{2}$ There have been no reports of life-threatening wild mushroom poisoning in Hong Kong before this case series.

Since its establishment in 2005, the Hong Kong Poison Information Centre (HKPIC) has provided a 24-hour telephone consultation service to health care professionals in Hong Kong for poison information and clinical management advice. We are actively involved in the diagnosis and management of mushroom poisoning cases in local hospitals. Supported by Prof SW Chiu from the School of Life Sciences of The Chinese University of Hong Kong, mycological identification can be provided whenever mushroom samples are available in a poisoning case. The objectives of this study were to review the clinical features and mycological identifications in mushroom poisoning cases recorded by the HKPIC.

\section{Methods}

Mushroom poisoning cases recorded by HKPIC from 1 July 2005 to 30 June 2015 were retrospectively reviewed. Information on patient demographic details, clinical presentation, sources of mushroom, investigation results, mycological identification

\section{香港進食蘑菇中毒的個案：十年病例回顧}

陳志強、林浩存、趙紹惠、謝萬里、劉飛龍

引言：進食蘑菇引致中毒甚至死亡的個案在世界各地均有發生。雖然 香港人喜歡進食蘑菇, 本地只有少數有關蘑菇中毒的臨床研究和病例 回顧。本研究旨在探討在香港進食蘑菇引致中毒的臨床症狀、中毒源 頭和治療結果。

方法：香港中毒諮詢中心回顧從2005年7月 1 日至2015年6月 30 日期間 所有轉介至該中心有關進食蘑菇引致中毒的病例。

結果：研究期間因進食蘑菇引致中毒共有67例，其中60例（90\%）出 現嘔吐、腹瀉和腹痛的腸胃症狀。53例為早發性（即進食蘑菇後6小 時內發病) 的腸胃症狀, 患者均屬於輕微中毒個案, 於接受症狀治療 和短暫住院後康復。7例的腸胃症狀為晚發性（即進食蘑菇後6小時或 以後才發病）, 患者全屬可致命的毒傘肽中毒個案。所有毒卒肽中毒 患者進食的均為野生採摘的蘑菇。3名患者在其他國家進食有毒蘑菇 後來港, 另 4 例含有毒麥肽的蘑菇均採自香港。7例毒莝肽中毒的病 例中, 6 例屬危重; 其中 1 例死亡, 2 例須接受肝臟移植。有 1 例在進 食市場上購買的蘑菇後出現迷幻蘑菇中毒, 中毒源頭為黑粉狍牛肝菌 （Tylopilus nigerrimus）。另有數宗中毒病例涉及從市面上購買的野 生乾牛肝菌。

結論：在香港發生的蘑菇中毒病例大多數出現腸胃症狀, 大部份為輕 微中毒個案。可致命的毒卒肽中毒病例偶有發生。假如病人在進食 磨菇6小時或以後才出現腸胃症狀, 醫生應考慮是否與毒卒肽中毒有 關。

results, and clinical outcome were obtained. Descriptive statistics were used for data analysis.

\section{Results}

During the 10-year study period, there were 67 cases of mushroom poisoning. All cases were reported from hospitals of the Hospital Authority. All patients were Chinese; 29 (43\%) were male and 38 (57\%) were female. The median age was 47 (range, 2-86) years. Of the 67 cases, 52 (78\%) occurred between April and September when the climate in Hong Kong is optimal for mushroom growth. In 66 cases, the mushrooms were intentionally consumed as delicacies. There was one case of accidental ingestion, in which a 2 -year-old boy ingested a wild mushroom in a park. Ingestion with recreational, suicidal, or malicious intent was not recorded in this case series.

The most common clinical presentation was gastrointestinal symptoms (Table 1). Symptoms mimicking gastroenteritis were the presenting feature in $60(90 \%)$ patients. The diagnosis of these 60 patients included gastroenteritic mushroom poisoning in 38 , cholinergic mushroom poisoning in five, food poisoning in eight, food allergy in two, and seven cases of amatoxin poisoning.

Neurological symptoms were also commonly reported: 20 (30\%) patients presented with one or more symptoms including dizziness, numbness, 
TABLE I. Presenting symptoms and signs

\begin{tabular}{|c|c|}
\hline Presenting symptom/sign & No. $(\%)$ of cases \\
\hline \multicolumn{2}{|l|}{ Gastrointestinal symptoms } \\
\hline Vomiting & $58(87)$ \\
\hline Diarrhoea & $49(73)$ \\
\hline Abdominal pain & $40(60)$ \\
\hline \multicolumn{2}{|l|}{ Neurological symptoms } \\
\hline Dizziness or lethargy & $10(15)$ \\
\hline Perioral or limb numbness & $5(7)$ \\
\hline Auditory or visual hallucination & $3(4)$ \\
\hline Confusion & $2(3)$ \\
\hline Miosis or blurred vision & $2(3)$ \\
\hline Headache & $1(1)$ \\
\hline Muscle fasciculation & $1(1)$ \\
\hline \multicolumn{2}{|l|}{ Other symptoms and signs } \\
\hline Excessive sweating & $7(10)$ \\
\hline Fever $\left(>38^{\circ} \mathrm{C}\right)$ & $7(10)$ \\
\hline Tachycardia (>100 beats/min) & $5(7)$ \\
\hline $\begin{array}{l}\text { Hypotension (systolic blood pressure } \\
<90 \mathrm{~mm} \mathrm{Hg} \text { ) }\end{array}$ & $4(6)$ \\
\hline Rash and generalised itchiness & $3(4)$ \\
\hline Jaundice & $2(3)$ \\
\hline Chill or shivering & $2(3)$ \\
\hline Urge to urinate & $2(3)$ \\
\hline Bradycardia & $1(1)$ \\
\hline Shortness of breath & $1(1)$ \\
\hline
\end{tabular}

hallucination, headache, or confusion (Table 1). Most of them (15 of 20 patients) presented with both neurological and gastrointestinal symptoms. Four patients presented with neurological symptoms including visual hallucinations, dizziness, generalised weakness, and malaise without gastrointestinal symptoms. They were subsequently diagnosed with hallucinogenic mushroom poisoning. One patient presented with malaise, muscle fasciculation, and profuse sweating that was diagnosed as cholinergic mushroom poisoning.

The symptom onset time was documented in 62 patients (Table 2). Among them, 53 patients developed symptoms within 6 hours of mushroom consumption (early-onset group). The median time of symptom onset was 2 hours post-ingestion (interquartile range [IQR], 2). Most patients (50 out of 53) presented with early-onset gastrointestinal symptoms. No severe clinical outcomes were observed in this group of patients and all recovered with symptomatic treatment and short duration of hospital care.

Symptoms developed 6 hours or more after mushroom consumption in nine patients (lateonset group). The median time of symptom onset was 11 hours post-ingestion (IQR, 2). This group of patients represented potentially life-threatening mushroom poisoning. All seven cases of amatoxin poisoning in this case series were found in this group. The remaining two cases included one case of hallucinogenic mushroom poisoning caused by

TABLE 2. Clinical diagnosis and outcomes

\begin{tabular}{|c|c|c|c|}
\hline \multirow[t]{2}{*}{ Clinical diagnosis and outcome } & \multicolumn{3}{|c|}{ Symptom onset time } \\
\hline & 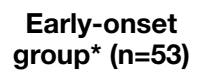 & $\begin{array}{l}\text { Late-onset } \\
\text { groupt }(n=9)\end{array}$ & $\begin{array}{l}\text { Not documented } \\
(n=5)\end{array}$ \\
\hline \multicolumn{4}{|l|}{ Clinical diagnosis } \\
\hline Amatoxin poisoning & 0 & 7 & 0 \\
\hline Gastroenteritic mushroom poisoning & 38 & 0 & 0 \\
\hline Cholinergic mushroom poisoning & 6 & 0 & 1 \\
\hline Hallucinogenic mushroom poisoning & 1 & 1 & 2 \\
\hline Food poisoning, possibly bacterial contamination & 5 & 1 & 2 \\
\hline Food allergy & 3 & 0 & 0 \\
\hline \multicolumn{4}{|l|}{ Clinical outcomes } \\
\hline Death & 0 & 1 & 0 \\
\hline Liver transplant & 0 & 2 & 0 \\
\hline $\begin{array}{l}\text { Severe cases managed in ICU or transplant centre, with full } \\
\text { recovery and without liver transplantation }\end{array}$ & 0 & 3 & 0 \\
\hline Managed in general ward or emergency ward ( $>1$ day stay) & 31 & 2 & 0 \\
\hline Discharged after treatment and brief observation in A\&E & 22 & 1 & 5 \\
\hline
\end{tabular}

Abbreviations: $\mathrm{A} \& \mathrm{E}=$ accident and emergency department; $\mathrm{ICU}=$ intensive care unit

* Symptom onset <6 hours after mushroom ingestion

$\dagger$ Symptom onset $\geq 6$ hours after mushroom ingestion 
Tylopilus nigerrimus, and one case of food poisoning.

The source of poisonous mushrooms was documented in 64 cases (Table 3). In 34 (51\%) cases, the mushrooms were self-picked from a park, hillside, or roadside. The locations were usually close to the patient's home. On the other hand, 14 (21\%) cases purchased the mushrooms in Hong Kong and $16(24 \%)$ purchased them in mainland China. All patients with amatoxin poisoning collected the mushroom from the wild. The source of mushrooms was not documented in three (4\%) cases.

Mycological identification was achieved in 28 cases (Table 4). The diagnosis of amatoxin poisoning was confirmed by the presence of amatoxin and/or phallacidin in the urine of five patients.

\section{Discussion}

The aim of this study was to describe the pattern of mushroom poisoning in Hong Kong. Four mushroom poisoning syndromes, together with food poisoning and food allergy, were identified to be the cause of all mushroom poisoning cases in this study. The typical clinical features and the management of the four local mushroom poisoning syndromes are summarised in Table $5 .{ }^{4}$

As an extensive urban city, commercially sold cultivated mushrooms are easily available and these are the mushrooms consumed by most Hong Kong citizens every day. Nonetheless the Chinese generally believes that wild-harvested products, including mushrooms, have higher nutritional and medicinal values. The risky behaviour of collecting and consuming wild mushrooms was considered to be rare in Hong Kong. This can be illustrated by the relatively few reported cases of poisoning during the study period. There are over 388 known species of mushroom in Hong Kong, ${ }^{5}$ of which fewer than $10 \%$ are edible, and a majority have unknown edibility. Although mushrooms are macroscopic organisms with visible morphological features, many mushroom species share a similar appearance and

TABLE 3. Source of poisonous mushroom and clinical diagnosis

\begin{tabular}{|c|c|c|c|c|c|c|c|}
\hline $\begin{array}{l}\text { Source of poisonous } \\
\text { mushroom }\end{array}$ & $\begin{array}{l}\text { Amatoxin } \\
\text { poisoning }\end{array}$ & $\begin{array}{c}\text { Gastroenteritic } \\
\text { mushroom } \\
\text { poisoning }\end{array}$ & $\begin{array}{l}\text { Cholinergic } \\
\text { mushroom } \\
\text { poisoning }\end{array}$ & $\begin{array}{l}\text { Hallucinogenic } \\
\text { mushroom } \\
\text { poisoning }\end{array}$ & $\begin{array}{c}\text { Food poisoning, } \\
\text { possibly } \\
\text { bacterial } \\
\text { contamination }\end{array}$ & Food allergy & Total \\
\hline \multicolumn{8}{|l|}{ Self-picked } \\
\hline In Hong Kong & 4 & 21 & 6 & 0 & 0 & 0 & 31 \\
\hline In mainland China & 1 & 0 & 0 & 0 & 0 & 0 & 1 \\
\hline In South Africa & 2 & 0 & 0 & 0 & 0 & 0 & 2 \\
\hline \multicolumn{8}{|l|}{ Purchased } \\
\hline In Hong Kong & 0 & 4 & 1 & 0 & 7 & 2 & 14 \\
\hline In mainland China & 0 & 13 & 0 & 3 & 0 & 0 & 16 \\
\hline No information & 0 & 0 & 0 & 1 & 1 & 1 & 3 \\
\hline
\end{tabular}

TABLE 4. Cases with mycological identification

\begin{tabular}{|c|c|c|c|}
\hline Diagnosis & $\begin{array}{l}\text { Proportion of cases } \\
\text { with mycological } \\
\text { identification }\end{array}$ & Causative mushroom (No. of cases) & Source (No. of cases) \\
\hline Amatoxin poisoning & $2 / 7$ & $\begin{array}{l}\text { Small whitish grey-capped ringless Amanita farinosa } \\
\text { (小托鵝亳菌) with a bulbous basal stem among edible } \\
\text { Auricularia auricula (2) }\end{array}$ & Self-picked in Hong Kong (2) \\
\hline $\begin{array}{l}\text { Gastroenteritic mushroom } \\
\text { poisoning }\end{array}$ & $20 / 38$ & $\begin{array}{l}\text { Russula emetica 毒紅菇 (2) } \\
\text { Chlorophyllum molybdites 綠禇菇 (7) } \\
\text { Macrolepiota neomastoidea 大環柄菇 (1) } \\
\text { Lepiota atrosquamulosa 黑鱗環柄菇 (1) } \\
\text { Mixing up of edible and inedible mushrooms (9) }\end{array}$ & $\begin{array}{l}\text { Purchased in China (2) } \\
\text { Self-picked in Hong Kong (7) } \\
\text { Self-picked in Hong Kong (1) } \\
\text { Self-picked in Hong Kong (1) } \\
\text { Purchased in Hong Kong (1) and China (8) }\end{array}$ \\
\hline $\begin{array}{l}\text { Cholinergic mushroom } \\
\text { poisoning }\end{array}$ & $3 / 7$ & $\begin{array}{l}\text { Mycena pura 潔小菇 (1) } \\
\text { Inocybe rimosa 裂絲蓋傘 (2) }\end{array}$ & $\begin{array}{l}\text { Self-picked in Hong Kong (1) } \\
\text { Self-picked in Hong Kong (2) }\end{array}$ \\
\hline $\begin{array}{l}\text { Hallucinogenic mushroom } \\
\text { poisoning }\end{array}$ & $1 / 4$ & Tylopilus nigerrimus 黑粉狍牛肝菌 (1) & Purchased in China (1) \\
\hline $\begin{array}{l}\text { Food poisoning, possibly } \\
\text { bacterial contamination }\end{array}$ & $2 / 8$ & $\begin{array}{l}\text { Rotten Boletus auripes 黄色牛肝菌 and Suillus } \\
\text { brevipes (Pk.) Kuntze 短柄乳牛肝菌 (2) }\end{array}$ & Purchased in Hong Kong (2) \\
\hline
\end{tabular}


TABLE 5. Mushroom poisoning syndrome reported in Hong Kong ${ }^{4}$

\begin{tabular}{|c|c|c|}
\hline Diagnosis & Clinical features & Management \\
\hline Amatoxin poisoning & $\begin{array}{l}\text { Gastrointestinal symptom onset at } 6-24 \text { hours post-ingestion, } \\
\text { followed by acute liver and renal injury. Potentially lethal }\end{array}$ & $\begin{array}{l}\text { Supportive care } \\
\text { Activated charcoal } \\
\text { Silibinin (intravenous) / silymarin (oral) } \\
\text { N-acetylcysteine } \\
\text { Penicillin G } \\
\text { Charcoal haemoperfusion and liver transplantation in } \\
\text { selected case }\end{array}$ \\
\hline $\begin{array}{l}\text { Cholinergic mushroom } \\
\text { poisoning }\end{array}$ & $\begin{array}{l}\text { Gastrointestinal upset, with additional cholinergic features } \\
\text { including profuse sweating, increased salivation, lacrimation, } \\
\text { bradycardia, and blurred vision. Typically early onset within } \\
0.5-2 \text { hours post-ingestion }\end{array}$ & $\begin{array}{l}\text { Supportive care } \\
\text { Activated charcoal } \\
\text { Atropine in selected case }\end{array}$ \\
\hline $\begin{array}{l}\text { Gastroenteritic mushroom } \\
\text { poisoning }\end{array}$ & $\begin{array}{l}\text { Vomiting and diarrhoea within } 0.5-3 \text { hours post-ingestion, and } \\
\text { resolved in } 6-24 \text { hours }\end{array}$ & $\begin{array}{l}\text { Supportive care } \\
\text { Activated charcoal }\end{array}$ \\
\hline $\begin{array}{l}\text { Hallucinogenic mushroom } \\
\text { poisoning }\end{array}$ & $\begin{array}{l}\text { Rapid-onset neuropsychiatric symptoms including visual } \\
\text { hallucinations, confusion, and delirium }\end{array}$ & $\begin{array}{l}\text { Supportive care } \\
\text { Activated charcoal } \\
\text { Benzodiazepines }\end{array}$ \\
\hline
\end{tabular}

misidentification is common. There is no correlation between a particular morphological feature and poisonous nature of a mushroom species. Even with genus Amanita, there are edible and inedible species. There is no simple way to differentiate edible and poisonous mushroom species. Even in expert hands, mushroom identification frequently depends on the microscopic features that can usually be seen in a laboratory setting. Different edible and inedible or poisonous mushroom species can share a similar habitat and grow in close proximity in the wild. Collection of mixed species often happens. Cooking or other means of food processing cannot detoxify a poisonous mushroom. With the report of life-threatening amatoxin poisoning from ingestion of local wild mushrooms, Hong Kong citizens would be well advised to stop the risky behaviour of consuming self-picked mushrooms from the wild.

Consumption of poisonous mushrooms can cause various signs and symptoms, such as gastroenteritis, disturbances in central nervous system, and liver failure. ${ }^{3}$ As mushroom identification is usually not available early on in patient care, doctors should treat their patients according to the clinical syndrome (Table $5^{4}$ ). An important predicting factor to consider is the latency from ingestion to onset of symptoms. The finding of our case series is compatible with overseas reports. ${ }^{3,6}$ Patients with early-onset symptoms, typically within 6 hours post-ingestion, all had a benign course of disease (Table 2). The mainstay of treatment is supportive, with intravenous fluids, antiemetic, antispasmodics, or analgesic for those patients who present with gastrointestinal symptoms.

Seven cases of amatoxin poisoning reported in this case series confirms the existence of deadly amatoxin-containing mushroom in our locality. Poisonous Amanita species have long been found in Hong Kong. Although local cases of amatoxin poisoning have not been reported in Hong Kong before 2013, it has been well-reported in mainland China. $^{7-9}$ According to a report published by Guangzhou Municipal Centre for Disease Control and Prevention, there were 92 cases of mushroom poisoning with 13 deaths in the years 2002 to $2005 .{ }^{9}$ The reported species of mushroom involved in $70 \%$ of cases were the amatoxin-containing mushroom Amanita exitialis and the gastroenteritic mushroom Chlorophyllum molybdites. ${ }^{9}$ For amatoxin poisoning, the latency between ingestion and onset of symptoms was typically 6 to 24 hours. ${ }^{3}$ For our seven cases of amatoxin poisoning, this latency ranged from 8 to 12 (median, 11) hours. There were four male and three female patients, with a median age of 44 (range, 29-74) years. All cases presented with persistent vomiting and diarrhoea, deranged liver function tests, and were able to give a history of wild mushroom ingestion. Three were imported cases. Two of them ate wild mushrooms in South Africa and one patient ate wild mushrooms in China. In four patients, wild mushrooms were picked locally in the country park of the New Territories. One imported case presented to hospital in Hong Kong 5 days after wild mushroom consumption and died of multi-organ failure soon after hospital admission. The remaining six cases were managed according to overseas experience in the treatment of amatoxin poisoning. ${ }^{10-12}$ Treatment included intravenous silibinin, oral silymarin, intravenous $\mathrm{N}$ acetylcysteine, oral multiple-dose activated charcoal, high-dose intravenous penicillin, and early charcoal haemoperfusion. Two local cases progressed to liver failure and required liver transplantation. The remaining four cases recovered with medical treatment. The diagnosis of amatoxin poisoning was confirmed by the presence of amatoxin and/or 
phallacidin in the urine in five patients. Mycological examination identified Amanita farinosa as the causative mushroom in a local incident with two patients (Table 4). This is the first report of this Amanita species in Hong Kong.

Hallucinogenic mushroom poisoning has not been previously reported locally. The clinical presentation of our four cases included dizziness, headache, generalised weakness and numbness. Three out of four patients presented with visual hallucination. Although one patient did not report any hallucinations, the patient was included as a suspected case of hallucinogenic mushroom poisoning based on compatible neurological symptoms following consumption of porcini. The symptom onset time was documented in two cases and was 2 hours and 10 hours post-ingestion. The source of mushroom was recorded in three cases as mainland China. In only one case was mycological identification performed (Table 4).

There were 13 cases of bolete poisoning in this case series. All cases were related to consumption of porcini. Porcini is considered to be a delicacy by many mushroom lovers. It includes a number of edible Boletus species, with Boletus edulis being the best known. Not all Boletus are edible, however, and mixing edible and inedible species is possible in wild mushroom harvesting. There are reports of bolete poisoning in English and Chinese literature. ${ }^{6}$ Bolete consumption has been associated with outbreaks of neuropsychiatric symptoms in Southwest China (eg Yunnan province) in recent years. ${ }^{13-15}$ According to these reports, consumption of inedible boletes typically presented with gastrointestinal and neurological symptoms including visual and auditory hallucination. In our case series, two out of 13 cases of bolete poisoning presented with neuropsychiatric symptoms without gastrointestinal symptoms. The two unrelated cases purchased mushrooms from Yunnan province. The first patient presented with numbness and weakness in all four limbs, dizziness, and malaise after mushroom consumption. The time of symptom onset was not documented and symptoms resolved on the same day as mushroom consumption. No mushroom sample was obtained for identification. The second patient developed dizziness, malaise, and visual hallucination 10 hours after mushroom consumption. Her symptoms resolved 48 hours post-ingestion. The causative mushroom was identified as Tnigerrimus, an inedible bolete. Hallucinogenic mushroom poisoning caused by $T$ nigerrimus has not been reported in the English literature.

In the cases of bolete poisoning, 11 out of 13 presented with gastrointestinal symptoms after mushroom consumption. Four patients purchased the mushrooms locally, and seven purchased the mushrooms in China. In most cases, the mushrooms were commercially packed as a product containing wild-harvested boletes in dried slices. Mycological identification was performed in 10 cases. These 10 cases represented six poisoning incidents. In five incidents involving eight patients, the wild-harvested porcini showed mixing up of edible porcini and inedible boletes. In the remaining one incident, the mushrooms were identified as an edible species, although microscopic examination revealed them to be rotten with dried worm and mold (Table 4). The diagnosis was food poisoning with possibly bacterial contamination of spoiled mushroom in this incident.

\section{Conclusion}

Most cases of mushroom poisoning in Hong Kong follow a benign course. Life-threatening cases of amatoxin poisoning are occasionally seen. Doctors should consider this diagnosis in patients who present with gastrointestinal symptoms whose onset is 6 hours or more after mushroom consumption. In this review, all patients with amatoxin poisoning picked the poisonous mushroom from the wild. Wild mushroom picking and consumption should be strongly discouraged.

\section{References}

1. Centre for Health Protection. Food poisoning associated with wild mushroom. Communicable Disease Watch 2005;2:41-2.

2. Chan TY, Chiu SW. Wild mushroom poisonings in Hong Kong. Southeast Asian J Trop Med Public Health 2011;42:468-9.

3. Diaz JH. Syndromic diagnosis and management of confirmed mushroom poisonings. Crit Care Med 2005;33:427-36.

4. Hoffman RS, Howland MA, Lewin NA, et al. Goldfrank's toxicologic emergencies. 10th edition. New York: McGrawHill Education; 2015.

5. Chang ST, Mao XL. Hong Kong mushrooms. Hong Kong: The Chinese University Press; 1995.

6. Schenk-Jaeger KM, Rauber-Lüthy $C$, Bodmer $M$, Kupferschmidt H, Kullak-Ublick GA, Ceschi A. Mushroom poisoning: a study on circumstances of exposure and patterns of toxicity. Eur J Intern Med 2012;23:e85-91.

7. Jin LM, Li Q. 金連梅, 李群. [Analysis of food poisoning incidents during 2004 to 2007 in China] 2004-2007年全國 食物中毒事件分析 [in Chinese]. [Disease Surveillance] 疾 病監測 2009;24:459-61.

8. Guo SH, Liu FQ, Liu XY, Chen Y. 郭綬衡, 劉富强, 劉 秀英, 陳炎. [Analysis of food-borne disease incidents in Jiangsu, Zhejiang, Hunan, Hubei and Hebei Province during 2000 to 2002] 2000-2002年江蘇、浙江、湖南、湖 北、河北五省食物源性疾病發病情况分析 [in Chinese]. [Practical Preventive Medicine] 實用預防醫學 2004;11:867-71.

9. Mao XW, Li YY, He JY, Jing QL. 毛新武, 李迎月, 何潔 儀, 景飲隆. [Investigation of mushroom poisoning in Guangzhou City from 2000 to 2005] 廣州市2000-2005年 蘑菇中毒調查 [in Chinese]. [China Tropical Medicine] 中 國熱帶醫學2007;7:166-7. 
10. Ward J, Kapadia K, Brush E, Salhanick SD. Amatoxin poisoning: case reports and review of current therapies. J Emerg Med 2013;44:116-21.

11. Enjalbert F, Rapior S, Nouguier-Soulé J, Guillon S, Amouroux N, Cabot C. Treatment of amatoxin poisoning: 20-year retrospective analysis. J Toxicol Clin Toxicol 2002;40:715-57.

12. Giannini L, Vannacci A, Missanelli A, et al. Amatoxin poisoning: a 15-year retrospective analysis and follow-up evaluation of 105 patients. Clin Toxicol (Phila) 2007;45:53942.

13. Ji X, Ma Z, Zhu H, Pan YZ. 及曉, 馬征, 朱輝, 潘軼竹.
[Report of two cases of mental disorder due to ingestion of Boletus speciosus] 小美牛肝菌所致精神障礙2例 [in Chinese]. [Clinical Journal of Psychiatry] 臨床精神醫學雜 誌 2014;24:240.

14. Liu MW, Zhou H, Hao L, Zhang MQ. 劉明偉, 周惠, 郝 麗, 張明謙. [Analysis of 61 cases of boletus poisoning] 牛肝菌中毒61例分析 [in Chinese]. [Chinese Journal of Misdiagnosis] 中國誤診學雜誌 2008;8:111.

15. Zhou YJ, Wei GL, Chen GH. 周亞娟, 魏桂蘭, 陳桂華. [Investigation of Rhubarb boletus food poisoning] 一起黄 粉牛肝菌食物中毒事件調查 [in Chinese]. [Occupational Health and Damage] 職業衛生與病傷 2008;23:115-6. 